\title{
Gene expression profiles during beta cell maturation and after IL-1 $\beta$ exposure reveal important roles of Pdx-1 and Nkx6.1 for IL-1 $\beta$ sensitivity
}

\author{
K. Nielsen ${ }^{1}$ M. Kruhøffer ${ }^{2}$ T. Ørntoft ${ }^{2}$ T. Sparre ${ }^{1}$ - H. Wang ${ }^{3}$ C. Wollheim ${ }^{3} \cdot$ M. C. Jørgensen ${ }^{4}$ J. Nerup ${ }^{1}$ • \\ A. E. Karlsen ${ }^{1}$ \\ ${ }^{1}$ Steno Diabetes Center, Gentofte, Denmark \\ 2 Department of Clinical Biochemistry, Aarhus University Hospital, Skejby, Aarhus, Denmark \\ ${ }^{3}$ Division of Clinical Biochemistry, Geneva University Medical Center, Geneva, Switzerland \\ ${ }^{4}$ Department of Developmental Biology, Hagedorn Research Institute, Gentofte, Denmark
}

\section{Abstract}

Aim/hypothesis. Maturation of the beta cells in the islets of Langerhans is dependent upon sequential activation of different transcription factors such as $\mathrm{Pdx}-1$ and Nkx6.1. This maturation is associated with an acquired sensitivity to cytokines and may eventually lead to type 1 diabetes. The aims of this study were to characterise changes in mRNA expression during beta cell maturation as well as after interleukin-1 $\beta$ (IL-1 $\beta$ ) exposure.

Methods. Transcriptome analyses were performed on two phenotypes characterised as a glucagon-producing pre-beta-cell phenotype (NHI-glu), which matures to an IL-1 $\beta$-sensitive insulin-producing beta cell phenotype (NHI-ins). Beta cell lines over-expressing Pdx-1 or Nkx6.1, respectively, were used for functional characterisation of acquired IL- $1 \beta$ sensitivity.

Results. During beta cell maturation 98 fully annotated mRNAs changed expression levels. Of these, 50 were also changed after $24 \mathrm{~h}$ of IL- $1 \beta$ exposure. In addition, 522 and 197 fully annotated mRNAs, not af- fected by maturation, also changed expression levels following IL-1 $\beta$ exposure of the beta cell and the prebeta-cell phenotype, respectively. Beta cell maturation was associated with an increased expression of Nkx6.1, whereas both Pdx-1 and Nkx6.1 expression were decreased following IL-1 $\beta$ exposure. Over-expression of Nkx6.1 or Pdx-1 in cell lines resulted in a significantly increased sensitivity to IL- $1 \beta$.

Conclusions/interpretation. These results suggest that the final beta cell maturation accompanied by increased IL-1 $\beta$ sensitivity is, in part, dependent upon the expression of genes regulated by $\mathrm{Pdx}-1$ and Nkx6.1. Future classification of the genes regulated by these transcription factors and changed during beta cell maturation should elucidate their role in the acquired sensitivity to IL-1 $\beta$ and may be helpful in identifying new targets for intervention/prevention strategies.

Keywords Beta cell maturation - IL- $1 \beta$ sensitivity and array analysis.
Received: 30 March 2004 / Accepted: 28 July 2004

Published online: 17 December 2004

C) Springer-Verlag 2004

A. E. Karlsen ( $)$

Steno Diabetes Center, Niels Steensensvej 2,

2820 Gentofte, Denmark

E-mail: aek@novonordisk.com

Tel.: +45-44 439043, Fax: +45-44 438232

Abbreviations: AS, argininosuccinate synthetase .

$\mathrm{BB}$, BioBreeding · EST, expressed sequence tag ·

GP, glutathione peroxidase · GST, glutathione- $S$-transferase *

$\mathrm{H}_{2} \mathrm{O}_{2}$, hydrogen peroxide $\cdot$ IL- $1 \beta$, interleukin- $1 \beta$.

iNOS, inducible nitric oxide synthase $\cdot$ JNK,

c-Jun NH2-terminal kinase · MAPK, mitogen activated

\section{Introduction}

The pancreatic endocrine cells (alpha, beta, gamma and PP) all arise from a common stem cell [1] and, dependent upon sequential activation of different tran-

protein kinase $\cdot \mathrm{Nkx6.1,} \mathrm{homeodomain} \mathrm{protein} \mathrm{Nkx6.1} \cdot \mathrm{NO}$, nitric oxide $\cdot \mathrm{Pdx}-1$, pancreatic duodenum

homeobox $1 \cdot$ RIN, rat insulinoma cells $\cdot$ SOCS-2, suppressor of cytokine signalling $2 \cdot$ WF, Wistar Furth

Electronic Supplementary Material

Supplementary material is available in the online version of this article at http://dx.doi.org/10.1007/s00125-004-1578-1 
scription factors, the stem cells mature into single-hormone-expressing cells (reviewed in [2]). In addition, mature alpha- and beta cells are believed to differentiate from two independent cell lineages [3] and timing of their differentiation relies on inhibitory signals from the Notch pathway [4]. The transcription factor pancreatic duodenum homeobox $1(\mathrm{Pdx}-1)$ has been demonstrated to be important both for pancreas development [5] and subsequent maturation of the endocrine cells [6], whereas later, in mature islets $\mathrm{Pdx}-1$, expression is restricted to the insulin-producing beta cells [4]. The homeodomain protein Nkx6.1, another transcription factor, is essential for the final maturation of the insulin-producing beta cells [7].

The mature insulin-producing beta cell is specifically sensitive to the toxic effects of cytokines, in particularly interleukin-1 $\beta$ (IL-1 $\beta$ ). Prolonged exposure to IL-1 $\beta$ has been demonstrated to severely suppress beta cell function, which in vivo might lead to the development of type 1 diabetes [8,9]. This beta-cellspecific sensitivity to cytokines is hypothesised to represent a trait acquired during beta cell maturation and is not characteristic of the other three endocrine cell types. Destruction of the beta cells has been associated with induction of highly reactive agents like oxygen-derived free radicals and nitric oxide (NO) [10], increased apoptosis [11], decreased insulin production and release [12] and decreased mitochondrial function [12]. Stimulation or over-expression of different defence mechanisms has been demonstrated to protect beta cells against the toxic effect of cytokines, streptozotocin, NO or reactive oxygen species [13, 14, 15].

In previous analyses of a cell system characterised as a glucagon-producing pre-beta-cell phenotype (NHI-glu), which matures to an insulin-producing beta cell phenotype (NHI-ins) [16, 17], we demonstrated that this maturation process was accompanied by sensitivity to the toxic effects of IL-1 $\beta$ [18]. This was substantiated by proteome analyses, demonstrating changes in protein expression levels affecting pathways previously shown to be of importance in IL- $1 \beta$ induced beta cell toxicity [19]. We hypothesise that changes in the mRNA expression profile, leading to susceptibility to IL-1 $\beta$ damage, are reflected in the transcriptome changes during beta cell maturation. Hence, the aims of the present study were to characterise changes in the mRNA expression profile accompanying the final maturation of the beta cell phenotype, as well as after IL- $1 \beta$ exposure of both phenotypes, using gene array technology [20]. The data obtained were compared to previous proteome analyses of IL-1 $\beta$-exposed Wistar Furth (WF) rat islets [21] and Bio Breeding (BB) rat islets [22], as well as transcriptome analyses of IL- $1 \beta$-exposed rat insulinoma (RIN) cells [23], cytokine-exposed purified beta cells [24] and INS-1E cells [25].

Interestingly, previous studies of the NHI-cell system showed that Pdx-1 was expressed in both the
NHI-ins and the NHI-glu phenotypes, whereas induced expression of Nkx6.1 was associated with maturation into the NHI-ins phenotype [26]. This was substantiated and extended in our array analyses to demonstrate that both Pdx-1 and Nkx6.1 were downregulated after IL-1 $\beta$ exposure exclusively in the beta cell phenotype. To elucidate the role of $\mathrm{Pdx}-1$ and Nkx6.1 in acquired IL-1 $\beta$-mediated toxicity, functional analyses were performed using two different cell systems: (i) the low Pdx-1 expressing rat insulinoma INS- $1 \alpha \beta$ cells transfected either with Pdx- 1 or a dominant-negative mutant form of Pdx-1 (DN-Pdx-1) [27]; and (ii) the glugacon-producing $\mathrm{Pdx}-1$ negative MSL-G-AN cell line transfected with Nkx6.1 [28].

The data are separated into three parts. The first part describes the mRNA changes during maturation of the pre-beta-cell phenotype to the beta cell phenotype and the effect of IL-1 $\beta$ on their expression levels. These data are presented and discussed in the manuscript. The second part focuses on the mRNAs of both phenotypes influenced by IL-1 $\beta$ exposure but not changed in expression level as a consequence of beta cell maturation. These data are presented and discussed on the web (web address). In both parts the relevance of the mRNAs of changed expression levels for beta cell survival and IL-1 $\beta$-induced beta cell destruction are discussed. The third part constitutes the functional characterisation of the effect of Pdx-1 and Nkx6.1 on the acquired sensitivity to IL-1 $\beta$ during beta cell maturation and is presented in the manuscript.

\section{Methods}

Cell culture. The NHI-cell system [18] is based on the prebeta-cell phenotype derived from the glucagon-producing MSL-G2 culture [29]. Following in vivo passage by transplantation in syngeneic NEDH rats, the pre-beta-cell phenotype (NHI-glu) matures into insulinomas [16, 30]. Insulinomas reestablished in vitro display an insulin-producing beta cell phenotype (NHI-ins) for prolonged periods of time [31], closely resembling beta cells with respect to their mRNA expression profile [26].

The two NHI-phenotypes were cultured in RPMI 1640 Glutamax (GibcoBRL Life Technologies, Paisley, Scotland, UK) supplemented with $10 \%$ FCS (GibcoBRL) and 1\% penicillin/streptomycin (GibcoBRL) at $37{ }^{\circ} \mathrm{C}$ in a $5 \% \mathrm{CO}_{2}$ atmosphere. For total RNA isolation used in the GeneChip array analyses four independent experiments were set up with $3 \times 10^{6}$ cells/well cultured in 6-well plates with or without $1500 \mathrm{pg} / \mathrm{ml}$ IL-1 $\beta$ for $24 \mathrm{~h}$ before lysis in a guanidinium thiocyanate/phenol buffer according to the manufacturer's instructions (RNAzol, Campro Scientific, Veenendaal, The Netherlands). The chosen concentration of IL-1 $\beta$ was based on our previous studies [18].

For the functional characterisation, two cell systems were used. One based on the tetracycline-inducible stably transfected INS-1r $\alpha \beta$ cells, with inducible expression of either Pdx-1 or a dominant-negative mutant form of Pdx-1 (DN-Pdx-1) [27]. The other cell system is the Pdx-1 and Nkx6.1 negative MSL-G-AN cells, stably transfected with Nkx6.1 (Nkx6.1 neg- 
ative clone $2 \# 584$ and Nkx6.1 positive clone $3 \# 589$ and clone 9 \#624) [28].

For measurement of the MTT-level 30,000 cells/well were set up in triplicates in 96-well plates (NUNC, Roskilde, Denmark) in six independent experiments. Following $24 \mathrm{~h}$ of preculture the cells were exposed for 3 days to human recombinant IL-1 $\beta$ (BD PharMingen, San Diego, CA, USA) at concentrations of either $20 \mathrm{pg} / \mathrm{ml}, 40 \mathrm{pg} / \mathrm{ml}$ or $160 \mathrm{pg} / \mathrm{ml}$. The selection of these IL- $1 \beta$ concentrations was based on a titration using different IL-1 $\beta$ concentrations $(0-2500 \mathrm{pg} / \mathrm{ml})$. This was performed to specify the IL- $1 \beta$ concentration yielding the highest differences (at least $50 \%$ reduction) in the mitochondrial activity, as a measure of viability, between the different cell types.

cRNA preparation and in vitro transcription. For the array analysis, $10 \mu \mathrm{g}$ total RNA was used as starting material for the cDNA preparation. The first and second strand cDNA synthesis was performed using the SuperScript II System (Invitrogen, Carlsbad, CA, USA) according to the manufacturer's instructions except for using an oligo-dT primer containing a T7 RNA polymerase promoter site. Labelled cRNA was prepared using the BioArray High Yield RNA Transcript Labelling Kit (Enzo Diagnostics, Farmingdale, NY, USA). Biotin-labelled CTP and UTP (Enzo) were used in the reaction together with unlabelled NTPs. Following the IVT reaction, the non-incorporated nucleotides were removed using RNeasy columns (Qiagen, Hilden, Germany).

Array hybridisation and scanning. Prior to array hybridisation, $15 \mu \mathrm{g}$ of cRNA was fragmented at $94{ }^{\circ} \mathrm{C}$ for $35 \mathrm{~min}$ in a frag-

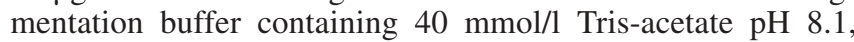
$100 \mathrm{mmol} / \mathrm{l} \mathrm{KOAc}$ and $30 \mathrm{mmol} / \mathrm{l} \mathrm{MgOAc}$. The fragmented cRNA in a $6 \times$ SSPE-T hybridisation buffer $(1 \mathrm{~mol} / 1 \mathrm{NaCl}$, $10 \mathrm{mmol} / 1$ Tris $\mathrm{pH} 7.6,0.005 \%$ Triton) was then heated to $95{ }^{\circ} \mathrm{C}$ for $5 \mathrm{~min}$ and subsequently to $45^{\circ} \mathrm{C}$ for $5 \mathrm{~min}$ before loading onto the Affymetrix RG_U34A probe array cartridge (Affymetrix, Santa Clara, CA, USA). The probe array was subsequently incubated for $16 \mathrm{~h}$ at $45{ }^{\circ} \mathrm{C}$ at constant rotation $(60 \mathrm{rpm})$. The washing and staining procedure was performed in the Affymetrix Fluidics Station. The probe array was exposed to ten washes in $6 \times \mathrm{SSPE}-\mathrm{T}$ at $25{ }^{\circ} \mathrm{C}$ followed by four washes in $0.5 \times \mathrm{SSPE}-\mathrm{T}$ at $50^{\circ} \mathrm{C}$. The biotinylated cRNA was stained with a streptavidin-phycoerythrin conjugate, final concentration $2 \mathrm{mg} / \mathrm{ml}$ (Molecular Probes, Eugene, OR, USA) in $6 \times$ SSPE-T for $30 \mathrm{~min}$ at $25^{\circ} \mathrm{C}$ followed by ten washes in $6 \times$ SSPE-T at $25^{\circ} \mathrm{C}$. An antibody amplification step followed using normal goat $\mathrm{IgG}$ as blocking reagent, final concentration $0.1 \mathrm{mg} / \mathrm{ml}$ (Sigma, St. Louis, MO, USA) and biotinylated antistreptavidin antibody (goat), final concentration $3 \mathrm{mg} / \mathrm{ml}$ (Vector Laboratories, Peterborough, UK). This was followed by a staining step with a streptavidin-phycoerythrin conjugate, final concentration $2 \mathrm{mg} / \mathrm{ml}$ (Molecular Probes) in 6x SSPE-T for $30 \mathrm{~min}$ at $25{ }^{\circ} \mathrm{C}$ and ten washes in $6 \times \mathrm{SSPE}-\mathrm{T}$ at $25^{\circ} \mathrm{C}$. The probe arrays were scanned at $560 \mathrm{~nm}$ using a confocal laserscanning microscope (Hewlett Packard GeneArray Scanner G2500A). The readings from the quantitative scanning were analysed by the Affymetrix Gene Expression Analysis Software.

MTT assay. As a measurement of viability based on the mitochondria activity the CellTiter 96 ${ }^{\mathrm{TM}}$ Non-Radioactive Cell Proliferation Assay (Promega, Madison, WI, USA), also known as the MTT assay was used [32]. In short, the cells were incubated with $15 \mu \mathrm{l} /$ well of the MTT solution. After $4 \mathrm{~h}$ of incubation, the reaction was stopped with $100 \mu$ l of the organic Solubilisation/Stop Solution and the absorbance at OD
$550 \mathrm{~nm}$ was recorded. Due to differences in proliferation rate between the phenotypes data are given as percent of control. A linear correlation between MTT-values and viability has previously been demonstrated by measuring both the release of lactate dehydrogenase and the incorporation of propidium iodide [18].

Semi-quantitative RT-PCR reactions. To confirm the array data, semi-quantitative RT-PCR analysis was performed on a selection of transcript. Total RNA was isolated after lysing the semi-confluent cells in a guanidinium thiocyanate/phenol buffer according to the manufacturer's instructions (RNAzol, Campro Scientific, Veenendaal, The Netherlands). cDNA synthesis was performed by oligo-dT primed reverse transcription of $1 \mu \mathrm{g}$ total RNA as described by the manufacturer (Invitrogen cDNA cycle Kit, CA, USA). Semi-quantitative RT-PCR [26] was carried out in $22 \mu \mathrm{l}$ reaction containing buffer (PCR running buffer, Invitrogen), $500 \mu \mathrm{mol} / \mathrm{l} \mathrm{dNTP}, 10 \mu \mathrm{mol} / \mathrm{l}$ primer, $50 \mathrm{mmol} / \mathrm{l} \mathrm{MgCl}_{2}, 5$ units/ $\mu \mathrm{l} \mathrm{Taq}$ polymerase (Invitrogen), $3000 \mathrm{Ci} / \mathrm{mmol}\left[\alpha^{-33} \mathrm{P}\right] \mathrm{dCTP}$ (Amersham Biosciences, Little Chalfont, UK) and $2 \mu \mathrm{l}$ cDNA as template. The following protocol was used: $95{ }^{\circ} \mathrm{C}$ for $5 \mathrm{~min}, 94{ }^{\circ} \mathrm{C}$ in $30 \mathrm{~s}$ for denaturation, $58-62{ }^{\circ} \mathrm{C}$ for $30 \mathrm{~s}$ for annealing and $72{ }^{\circ} \mathrm{C}$ in $30 \mathrm{~s}$ for extension in 24 to 32 cycles dependent on the transcript, followed by a single extension period at $72{ }^{\circ} \mathrm{C}$ for $10 \mathrm{~min}$. To compensate for variation in cDNA concentrations and PCR efficiency between tubes, an internal standard ( $\beta$-tubulin, G6PDH or TBP) was enclosed in each amplification and used for normalisation.

The primers used were based upon sequences obtained from GeneBank:

Pdx-1: 5'-ggacatctcccatacgaag-3', 5'-cgttgtcccgetactacgtt-3', \#NM_022852, 454 bp;

Nkx6.1: 5' -acttggcaggaccagagaga-3', 5' -gggcttgttgtaatcgtcgt3', \#AF004431, 209 bp;

G6PDH: 5'-agaaccacctcetgccgatg-3', 5' -tcccaccgttcattctccac3', \#, X07467, 270 bp;

C-myc: 5'-acggcettctcttcttcctc-3', 5'-gtttgctgtggcctcttgat-3', \#Y00396, 225 bp;

Ins I/II: 5' -ctgcccaggcttttgtcaa-3', 5' -gttgcagtagttctccagttggt-3', \#NM_019129/019130, 269 bp;

$\beta$-tubulin: $5^{\prime}$-gagctgttcaagcgcatctc- $3^{\prime}, 5^{\prime}$-atcctggtactgctggtact3', \#XM_238004, 156 bp;

GP: 5'-cgcaacgacatttcctggaa-3', 5'-agccatcaccaagcccagata-3', \#X07365, 176 bp;

TBP: $5^{\prime}$-accettcaccaatgactcctatg- $3^{\prime}, 5^{\prime}$-atgatgactgcagcaaatcgc3', \#D01034, 190 bp.

The reaction products were separated by $6 \%$ Novex TBE Gels (Invitrogen). Control experiments with amplification of RNA alone did not reveal any contaminating genomic DNA influencing the results. After drying and exposure of the gel to a PhosphoImage storage screen, the transcription products were scanned and quantified on a PhosphorImager using the ImageQuant software (Molecular Dynamics, UK), and expressed relatively to the internal standard co-amplified in each PCR reaction.

Immunocytochemistry. To establish the level of Nkx6.1 in the MSL-G-AN cell system immunocytochemical peroxidase staining of monolayer cells were carried out with the Histostain-Plus kit (Zymed Laboratories, San Francisco, CA, USA). The generation of rabbit antiserum against Nkx6.1 has previously been described [26]. Anti-Nkx6.1-174 was diluted 1:5000. Pre-immune serum (1:4000) was used as negative control and no signal was detected (data not shown). 
Statistical analysis. The average and standard deviation (SD) on the GeneChip are calculated based upon four independent samples from each experimental condition. The average of the fold change (FC) is based on 16 cross-comparisons between the two sets of samples $(4 \times 4)$ [20]. FC values above 1 represents up-regulated transcripts and FC values below -1 represent down-regulated transcript. A two-sided non-paired $t$ test was used for statistical analysis of the GeneChip analyses and the significance level was defined as $p<0.01$. Thus, only transcripts with a FC value below -1 or above 1 and with a $p$ value below 0.01 were accepted as significantly changed in expression. During beta cell maturation some of the transcripts have changed their expression level either from or to an expression level around the detection limit of the GeneChip array analysis (indicated by an ' $\wedge$ ' behind the FC value in Table 1). This is the reason why some of the $\mathrm{FC}$ values are very high.

Results from the MTT analyses are presented as means \pm $\mathrm{SD}$ of six independent experimental setups. A two-sided $t$ test was used for statistical analysis. When comparing the effect of doxycycline within one phenotype, paired analyses were performed, and when comparing the effect of IL-1 $\beta$ between the different phenotypes, non-paired analyses were performed.

In both cases the level of significance was chosen at $p<0.05$.

\section{Results}

The GeneChip used in these analyses provides approximately $8800 \mathrm{mRNAs}$ including both full-length mRNAs and ESTs. Several mRNA changes were found after beta cell maturation as well as after IL- $1 \beta$ exposure of both phenotypes. Figure 1 is included to facilitate the presentation of data. Changes during maturation from the pre-beta-cell to the beta cell phenotype are included in group A and of these, the mRNAs also changing expression level in response to IL$1 \beta$ are subgrouped into group $X$ (exclusively in the pre-beta-cell phenotype), group Y (exclusively in the beta-cell phenotype) and group Z (in both phenotypes). These data are presented in Table 1 in the manuscript. mRNAs not influenced by the maturation process but changing expression levels after IL- $1 \beta$ exposure exclusively in the pre-beta-cell phenotype (group B), in the beta cell phenotype (group C) or in both (group Q) are grouped separately and are presented in Tables B, C and Q respectively (see Electronic Supplementary Material, where the results are also discussed).

Transcript profile reflecting beta-cell maturation and associated IL-1 $\beta$ response (Part I). After beta cell maturation 98 fully annotated mRNAs and 42 ESTs were significantly $(p<0.01)$ changed in expression levels when compared to the pre-beta-cell phenotype (Fig. 1, group A). The mRNAs have been assigned to functional groups according to their known or putative functions and the fold change (FC) in the expression levels are given in Table 1, panel A. Due to the lack of full annotation, the ESTs identified in the present study are not further discussed, but a full list is avail- able online (Table $\mathrm{A}^{\mathrm{EST}}$, web address). Of the 98 fully annotated mRNAs (46 up-regulated and 52 down-regulated), a total of 50 mRNAs were also affected significantly by IL-1 $\beta$. Of these 14 were exclusively changed in the pre-beta-cell phenotype (group X), 13 exclusively in the beta cell phenotype (group Y) and 23 in both phenotypes (group Z). The FC values are listed in Table 1, panel B. Several of these mRNAs have previously been shown to be influenced by IL-1 $\beta$ in proteome analyses of WF rat islets (\&\#164;) [21] and $\mathrm{BB}$ rat islets (\#) [22] or to be influenced by IL-1 $\beta$ or cytokine combinations in array analyses of RIN cells $(*)$ [23], purified beta cells $(\S)$ [24] or INS-1E cells (\&) [25] (indicated in Table 1, column 1). Due to printing space restrictions only some of these mRNAs previously shown to changed in proteome and transcriptome analyses as well as mRNAs known to be relevant for beta-cell maturation or beta-cell destruction are discussed.

To validate the array-analysis, a subset of five transcripts with variable expression during beta cell maturation and/or in response to IL-1 $\beta$ was selected for semi-quantitative RT-PCR analysis (Fig. 2 and Table 2). In agreement with the results from the GeneChip array analysis (Table 1) we observed an increased mRNA expression of c-myc and insulin during beta cell maturation. In line with previous analysis [26] semi-quantitative RT-PCR analysis (Fig. 2) confirmed an induced expression of Nkx6.1 in the beta cell phenotype. In addition, confirmation of induced glutathione peroxidase (GP; Fig. 2) in the beta cell phenotype was detected. The IL-1 $\beta$-induced downregulation of Nkx6.1 in the beta cell phenotype detected in the GeneChip array analysis (Table 1; FC -3.1) was confirmed in the RT-PCR assay (Table 2; $0.8 \pm 0.1$ vs $0.3 \pm 0.03$ ). In line with the GeneChip array data and previous publication [26] Pdx-1 was confirmed by RTPCR to be expressed at an equal level in both phenotypes. The expression level was reduced in response to IL-1 $\beta$ (Table 2 ) in both phenotypes and the array data showed a similar reduction in the IL-1 $\beta$ exposed beta cell phenotype (FC -1.4 , Table $\mathrm{C}$, web address).

Transcript profile of both phenotypes influenced by $I L-1 \beta$ but not by beta-cell maturation (Part II). In addition to the 50 fully annotated mRNAs affected both by beta cell maturation and IL- $1 \beta$ exposure, a large number of mRNAs not affected during beta cell maturation were significantly $(p<0.01)$ changed in expression level following IL- $1 \beta$ exposure of the two phenotypes. Thus, 197 fully annotated mRNAs (98 up-regulated, 99 down-regulated and 262 ESTs) were exclusively changed in the pre-beta-cell phenotype (Fig. 1 group B, Table B and Table BEST in Electronic Supplementary Material). In the beta cell phenotype 522 fully annotated mRNAs (251 up-regulated, 271 downregulated and 477 ESTs) were exclusively changed (Fig. 1 group C, Table $\mathrm{C}$ and Table $\mathrm{C}^{\mathrm{EST}}$ in Electronic 
Table 1. Transcript profile reflecting beta cell maturation and associated IL-1 $\beta$ response

mRNAs
Data acc. \# Panel A

Beta cell maturation

FC

$\begin{array}{lrr}\text { E00001 } & 7.0 & 31.9 \\ \text { L05489 } & 2.7 & 13.3 \\ \text { S54008 } & -4.6 & 8.8 \\ \text { U67080 } & -6.1 & 11.2 \\ \text { M25890 } & -170.0^{\wedge} & 357 . \\ \text { M58634 } & -21.5^{\wedge} & 39.4 \\ \text { K02248 } & -56.9^{\wedge} & 59.7 \\ \text { AF004431 } & 10.0^{\wedge} & 7.6 \\ \text { Y00396 } & 19.5^{\wedge} & 8.5 \\ \text { J04807 } & 64.5^{\wedge} & 52 . \\ \text { X17012 } & -1.7 & 55.4 \\ \text { M18416 } & -3.1 & 26.2 \\ \text { L26292 } & -3.4 & 7.2\end{array}$

X06890

M97380

AF051561

U53211

AJ223355

M90398

AF040261

Y00826

L28135

M93669

Secretogranin II

3. Glycolysis and energy generation:

Hexokinase II

Pyruvate kinase

Pyruvate dehydrogenase phosphatase isoenzyme 1

Aldolase B (X 02284)

Fructose-1,6-bisphosphatase (\&\#164;)

Creatine kinase (M57664) (§)

4. Chemokines, cytokines and related receptors:

Interleukin 18 (IL-18)

5. Cell cycle, cell adhesion, cytoskeleton and differentiation:

Rat skeletal muscle alpha-actin gene

Ssecks $322(\S)$

Syndecan

Galectin-5 (\&)

Cyclin G

Focal adhesion kinase

Inhibitor of DNA-binding Id1.25

Claudin-9

C-CAM4

Lactose-binding lectin (galectin-4)

Heat sle antigen CD24 (\$)

D26393

X05684

AF062740

$\mathrm{X} 02291$

AJ005046

M57664

AJ222813

J00692

U75404

S61865

L21711

X70871

S83358

L23148

AJ011811

U23056

M73553

U49062

6. MHC and immune-mediated mechanisms:

CD200

7. Signal transduction:

MAP-kinase phosphatase (cpg21) (§)

Regulator of G-protein signalling 4 (*)

Dual specificity phosphatase (MKP-3)
Panel B

IL-1 $\beta$ exposure

\begin{tabular}{lll}
\hline SG & NHI-ins & NHI-glu \\
& FC & FC
\end{tabular}


Table 1. (contined)

mRNAs
Data acc. \#

Panel A
Beta cell maturation
FC

FC SD

Panel B

IL-1 $\beta$ exposure

\begin{tabular}{lll}
\hline SG & NHI-ins & NHI-glu \\
& FC & FC
\end{tabular}

Suppressor of cytokine signalling-2 (SOCS-2)

Inositol-1,4,5-triphosphate receptor

Phospholipase C delta-4

Inositol-1,4,5-triphosphate binding protein $(*)$

AF075382
J05510
U16655
D45920

3.2

2.6

$-11.7^{\wedge}$

4.0

5.8

D45920

X12459

$-16.6^{\wedge}$

28.6

36.3

8. Arginine/nitrogen metabolism and NO formation:

Argininosuccinate synthetase (AS) $(\S, \&)$

9. Apoptosis:

Fibrinogen B beta chain $(\S, *)$

U05675

$-5.8$

44.6

10. Defence/repair:

Glutathione $S$-transferase M5 (mu) (*)

Glutathione peroxidase $(\S)$

Gas-5 growth arrest $(\S, \&)$

Metallothionein-1 and 2 (§)

Glutathione $S$-transferase

Glutathione $S$-transferase Yc (alpha) (X78848)

12. Degradation, proteasome and peptidases:

Membrane-type matrix metalloproteinase

Serine proteinase inhibitor-like protein $(*)$

Matrix metalloproteinase-13

13. Amino acid (without arginine), ornithine, purine and pyrimidine metabolism:

L-arginine-glycine amidinotransferase

Glutamine synthetase $(*)$

U07971

M91652

U86635

U77829

M11794

J03752

K01932

2.2
$34.6^{\wedge}$
$2.8^{-2}$
$-2.2^{\wedge}$
$52.6^{\wedge}$
$8.6^{\wedge}$

$-10.2^{\wedge}$
$-13.7^{\wedge}$
-3.4

126.8

4.8

$$
2.3
$$

81.2

24.3

9.6

X83537

$\mathrm{X} 16273$

$-3.4$

26.1

29.3

64.2

$\begin{array}{ll}4.5 & 4.5\end{array}$

$2.4 \quad 20.4$

X14181

$-1.4$

240.2

Ribosomal protein L18a

15. Lipids and fatty acid metabolism:

Acyl-CoA synthetase

Stearyl-CoA desaturase

Steroid 5 alpha-reductase $(\S, \&)$

D85189

J02585

J05035

4.1

3.0

$-3.4$

8.2

28.3

66.9

$\begin{array}{ll}\mathrm{Y} & -1.7 \\ \mathrm{Z} & -2.2\end{array}$

$-3.0$

16. Neurons:

Delta-preprotachykinin

Limbic system-associated membrane protein

Beta-tachykinin

Tyrosine hydroxylase

Aromatic L-amino acid decarboxylase $(\S, *)$

GABA-A receptor delta subunit

Peripherin

Neuron-specific protein PEP-19 (*)

Monoamine oxidase A

Substance $\mathrm{P}$ receptor

C1-13 gene product

20. Miscellaneous:

Calcitonin receptor $\mathrm{C} 1 \mathrm{~b}$

Gastrin

Oestrogen receptor

Vesl-2 (delta 11)

Thy-1 gene for cell-surface glycoprotein

Angiotensinogen

Sprague-Dawley tissue factor protein $(*)$

Plasma cell membrane glycoprotein (PC1)

Cholecystokinin type-A receptor $(\S)$

Beta-galactoside-alpha 2,6-sialyltransferase (§)
X56306

U31554

M15191

M10244

M84648

M35162

AF031878

M24852

S45812

M64236

X52817

$-10.2 \quad 72.4$

$-12.2^{\wedge} \quad 7.4$

$-6.0 \quad 126.6$

$-15.2^{\wedge} \quad 26.5$

$4.7 \quad 14.2$

$1.9 \quad 15.5$

$8.3^{\wedge} \quad 10.4$

$\begin{array}{ll}5.3 & 2.7\end{array}$

$2.7 \quad 7.2$

$\begin{array}{ll}4.2 & 45.7\end{array}$

$1.7 \quad 123.1$

$\begin{array}{ll} & -1.5 \\ \mathrm{Y} & -1.9 \\ \mathrm{Z} & -1.9\end{array}$

$-2.6$

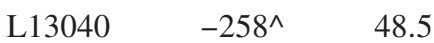

M38653 $-12.5^{\wedge} \quad 26.0$

S52128

AB007690

$-6.4^{\wedge}$

26.0
14.1

AA874848

M12112

U07619

AB017596

$-4.7^{\wedge} \quad 9.3$

$-7.6^{\wedge} \quad 13.2$
-2.6

$-2.6 \quad 415.0$

$\begin{array}{ll}-1.8 & 23.7\end{array}$

$-3.9 \quad 32.1$

D50608

M83143 
Table 1. (contined)

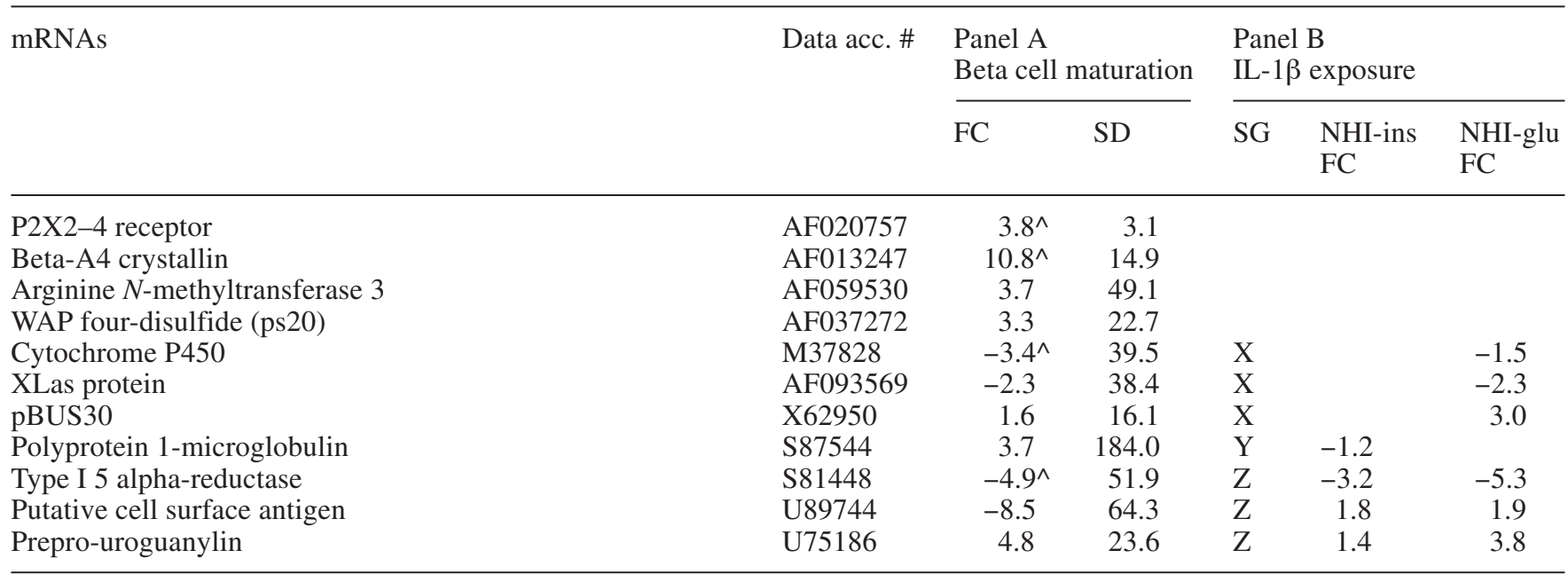

Panel A shows the fold change (FC) values of transcripts that significantly $(p<0.01)$ changed expression level during maturation from the pre-beta cell (NHI-glu) to the beta cell phenotype (NHI-ins). Panel B shows the FC values of transcripts that, in addition, are affected by IL- $1 \beta$ exposure. The transcripts are listed according to their major known function with their database accession number (Data acc. \#). FC values are given relative to control values in the two phenotypes. The subgroup assignment ( $\mathrm{SG}$ ) refers to Figure 1. A negative FC value represents a down-regulated and a positive value an up-regulated expression level. An ' $\wedge$ ' in the FC columns indicates that the transcript is expressed at a low level around the detection limit in one of the conditions compared. The results are from four independent experiments and the standard deviations (SD) from the NHI-glu phenotypes are shown. Symbols illustrate that similar changes have previously been reported in (\&\#164;) IL-1 $\beta$ exposure of WF rat islets [21], (\#) IL-1 $\beta$ exposure of BB rat islets [22], (*) IL-1 $\beta$ exposure of RIN cells [23], (\$) cytokine exposure of purified beta cells [24] or (\&) cytokine exposure of INS-1E cells [25]

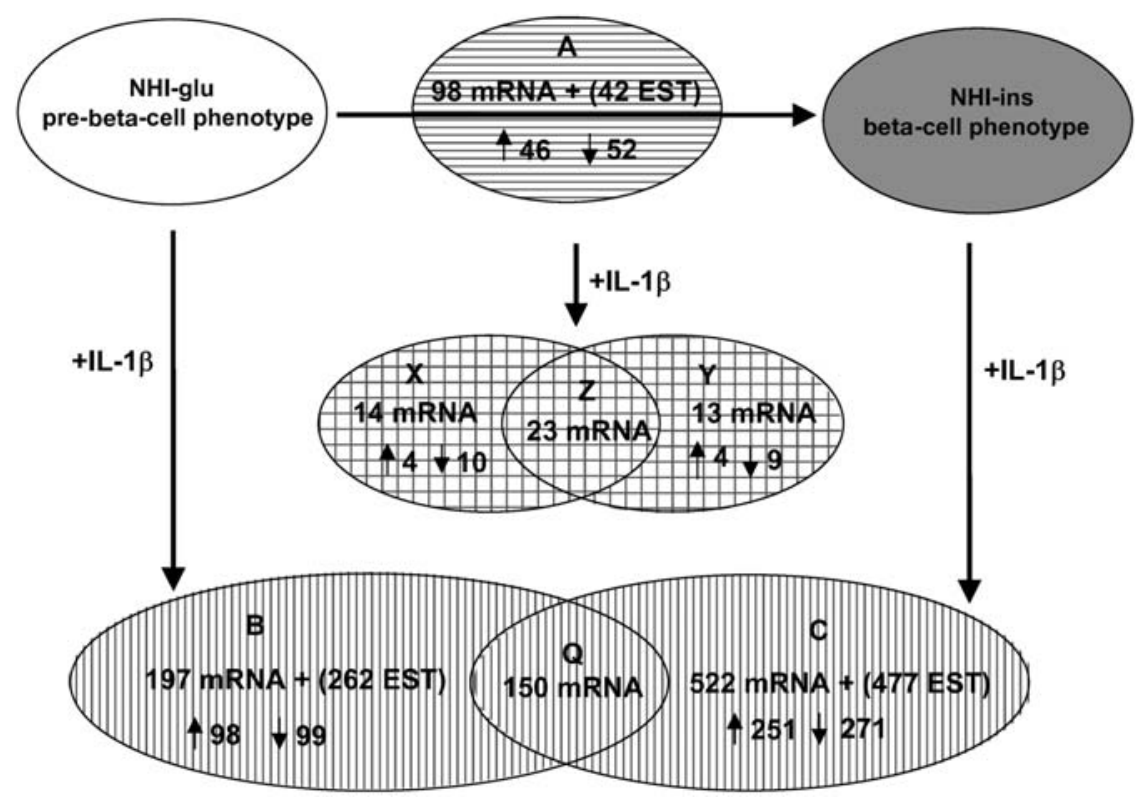

Fig. 1. Experimental out-line and data-grouping. Schematic illustration of the NHI-beta-cell maturation system from the NHI-glu pre-beta-cell (white) to the NHI-ins beta cell (grey) phenotype. Changes during this maturation are found in group $A$ and illustrated by horizontal lines (Table 1, panel A). Of these transcripts also affected by IL- $1 \beta$ exposure exclusively in the pre-beta-cell phenotype (group $\mathrm{X}$ ), beta cell phenotype (group Y) or in both phenotypes (group Z) are illustrated by both horizontal and vertical lines (Table 1, panel B). Transcript changes not affected during beta cell maturation but only after IL-1 $\beta$ exposure of the pre-beta-cell phenotype (group B, Table $\mathrm{B}$, web address), the beta cell phenotype (group C, Table C, web address) or both phenotypes (group Q, Table Q, web address) are illustrated by only vertical lines. This group assignment has been used for each transcript listed in Table 1 


\section{$\mathrm{NHI}$-glu NHI-ins}

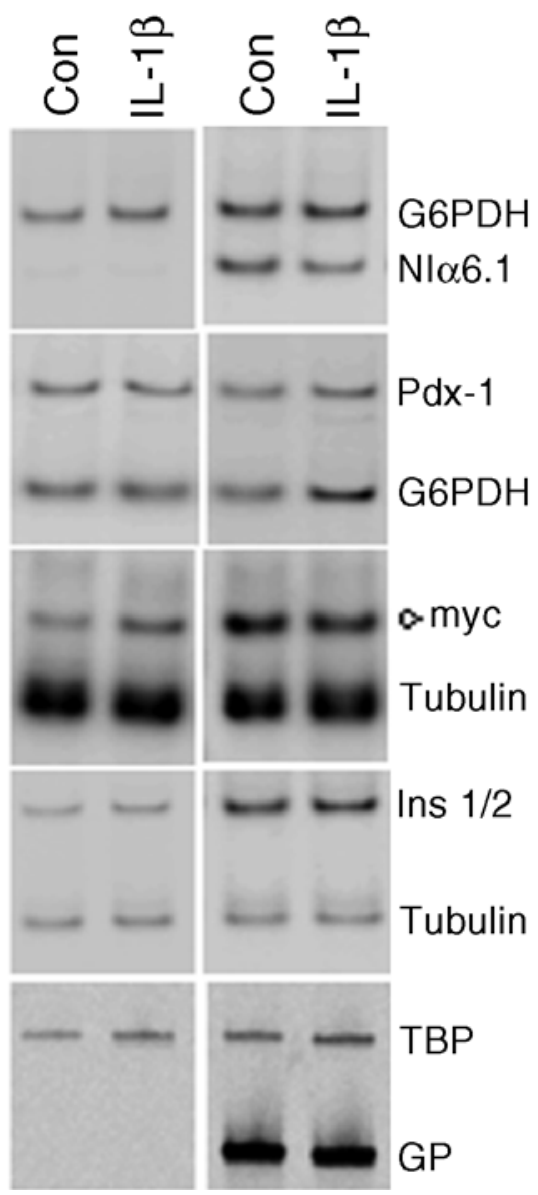

Fig. 2. Semi-quantitative RT-PCR analysis of mRNA expression. Representative autographs from semi-quantitative RTPCR analyses of selected transcripts of different expression level identified from the GeneChip array analysis. The expression is shown for the NHI-glu (left panel) and NHI-ins (right panel) in the absence or presence of IL-1 $\beta$. The levels of Pdx-1 and Nkx6.1 were normalised to the internal standard G6PDH, c-myc and insulin I/II were normalised to $\beta$-tubulin, whereas GP was normalised to TBP. Quantitative data from 3 to 4 independent experiments are available in Table 2
Supplementary Material) and 150 fully annotated $\mathrm{mR}$ NAs were changed in both phenotypes (Fig. 1 group Q, Table Q in Electronic Supplementary Material). Due to printing space restrictions data from group B, $\mathrm{C}$ and $\mathrm{Q}$ as well as discussion of some of these are restricted to the web (web address).

Functional analyses of Pdx-1 and Nkx6.1 (Part III). Nkx6.1 was identified as an up-regulated mRNA during beta-cell maturation. Furthermore, both Nkx6.1 and Pdx-1 were down-regulated after IL- $1 \beta$ exposure of the beta cell phenotype but not affected in the prebeta-cell phenotype. The effect of induced Pdx-1 or Nkx6.1 expression on the acquired beta cell sensitivity to IL-1 $\beta$ was therefore further addressed using a low Pdx-1 expressing rat insulinoma cell line (INSr $\alpha \beta$ ) with doxycycline inducible $\mathrm{Pdx}-1$ expression and the MSL-G-AN cells with a stable Nkx6.1 expression, respectively. First, a titration was performed to identify the IL-1 $\beta$ concentration required to reduce the viability of the Pdx-1 as well as Nkx6.1 expressing cells by approximately $50 \%$ over 3 days (data not shown). At these conditions the cells die primarily by apoptosis rather than necrosis and a potential effect of Pdx-1 or Nkx6.1 is best detected in the two cell systems. This effect was obtained in the INSr $\alpha \beta$-cell line at $20-40 \mathrm{pg} / \mathrm{ml} \mathrm{IL-1} \beta$ when Pdx-1 was induced by doxycycline. A subsequent study using 20 and $40 \mathrm{pg} / \mathrm{ml} \mathrm{IL}-1 \beta$ in six independent assays confirmed that induction of $\mathrm{Pdx}-1$ resulted in a significant $(p<0.001)$ approximately $50 \%$ reduction in viability of the Pdx-1 transfected INS-1 cells (Fig. 3). In contrast, no effects of 20 or $40 \mathrm{pg} / \mathrm{ml}$ IL- $1 \beta$ on the viability was observed in neither the DN-Pdx-1 nor the Pdx-1 transfected cells in the absence of doxycycline. Furthermore, in control experiments no effect of IL$1 \beta$ was observed in the DN-Pdx-1 transfected cells after addition of doxycycline, demonstrating that the effect on the Pdx-1 transfected cells is not mediated by the doxycycline, but indeed reflects an increased

Table 2. Semi-quantitative RT-PCR analysis of mRNA expression

\begin{tabular}{|c|c|c|c|c|c|c|c|}
\hline \multicolumn{4}{|c|}{ Beta cell maturation: } & \multicolumn{4}{|c|}{ IL-1 $\beta$ exposure: } \\
\hline mRNA & NHI-glu & NHI-ins & $\begin{array}{l}p \text { value } \\
\text { NHI-ins vs } \\
\text { NHI-glu }\end{array}$ & NHI-glu & NHI-ins & $\begin{array}{l}p \text { value } \\
\text { IL- } 1 \beta \text { vs } \\
\text { NHI-glu }\end{array}$ & $\begin{array}{l}p \text { value } \\
\text { IL- } 1 \beta \text { vs } \\
\text { NHI-ins }\end{array}$ \\
\hline Nkx6.1 & nd & $0.8 \pm 0.1$ & $<0.001$ & nd & $0.3 \pm 0.03$ & NS & $<0.001$ \\
\hline $\mathrm{Pdx}-1$ & $0.5 \pm 0.07$ & $0.7 \pm 0.2$ & ns & $0.3 \pm 0.05$ & $0.4 \pm 0.05$ & 0.01 & 0.03 \\
\hline GP & nd & $1,102 \pm 147$ & $<0.001$ & $50 \pm 56$ & $1,135 \pm 699$ & upper case ( 5 times) & NS \\
\hline
\end{tabular}

The influence of beta cell maturation and IL-1 $\beta$ exposure on selected transcripts was analysed by semi-quantitative RTPCR. The mRNA expression levels of Pdx-1 and Nkx6.1 were normalised to the internal standard G6PDH, c-myc and insulin
I/II were normalised to $\beta$-tubulin, whereas GP was normalised to TBP. The data are mean ratio \pm SD from three or four independent experiments. nd, not detectable 


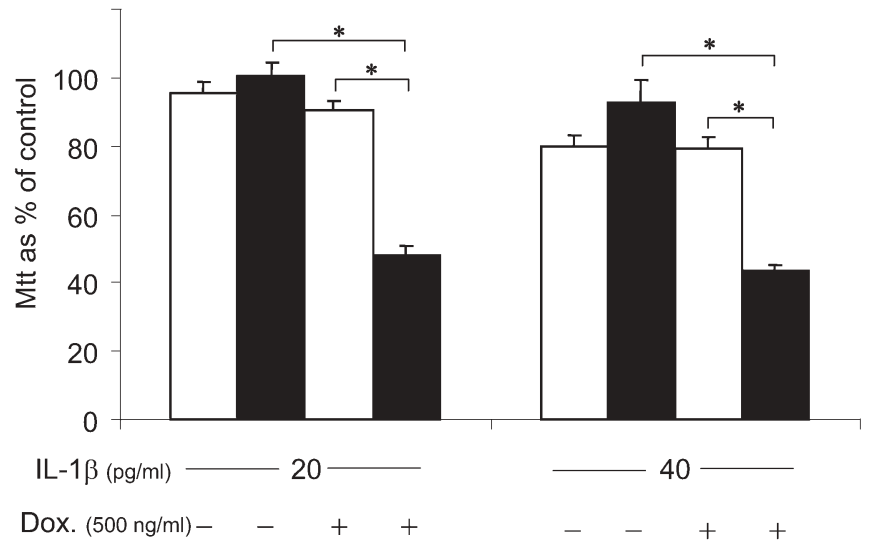

Fig. 3. Effect of Pdx-1 on IL-1 $\beta$-induced toxicity. Viability, measured as MTT activity (percent of control) in INS-1 cells transfected with Pdx-1 (black bars) or DN-Pdx-1 (white bars) cultured without or with doxycycline (dox; $500 \mathrm{ng} / \mathrm{ml})$. The cells were stimulated with IL- $1 \beta(20 \mathrm{pg} / \mathrm{ml}$ or $40 \mathrm{pg} / \mathrm{mg})$ for 3 days and the data are mean \pm SD of triplicate determinations from six independent experiments. Significant differences $\left(^{*}\right.$, $p<0.001)$ relative to conditions without dox or between the two phenotypes are indicated

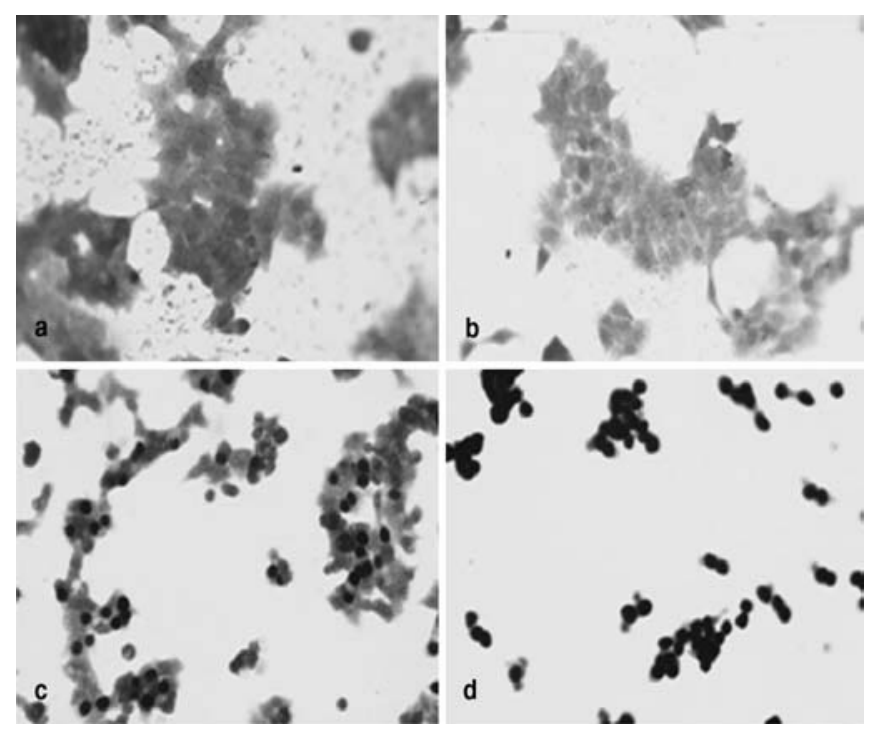

Fig. 4. Nkx6.1 expression in the MSL-G-AN cell system. Immunocytochemical peroxidase staining of Nkx6.1 expression in clones used in the functional analyses presented in Figure 5. Approximately $50 \%$ of the cells in clone \#589 (c) and $100 \%$ of the cells in clone \#624 (d) express Nkx6.1 shown as distinct red staining of the cell nuclei. In contrast, no Nkx6.1 expression was found in MSL-G-AN (a) and clone \#584 (b)

sensitivity to IL- $1 \beta$ in response to the induced $\mathrm{Pdx}-1$ expression.

The effect of Nkx6.1 expression on acquired IL-1 $\beta$ sensitivity was addressed using two clones obtained by stable transfection of a Pdx-1 and Nkx6.1 negative rat insulinoma cell line (MSL-G-AN) with Nkx6.1 (clone \#589 with medium or clone \#624 with high Nkx6.1 expression) (Fig. 4). No Nkx6.1 expression was detected in either the parent cell line MSL-G-AN

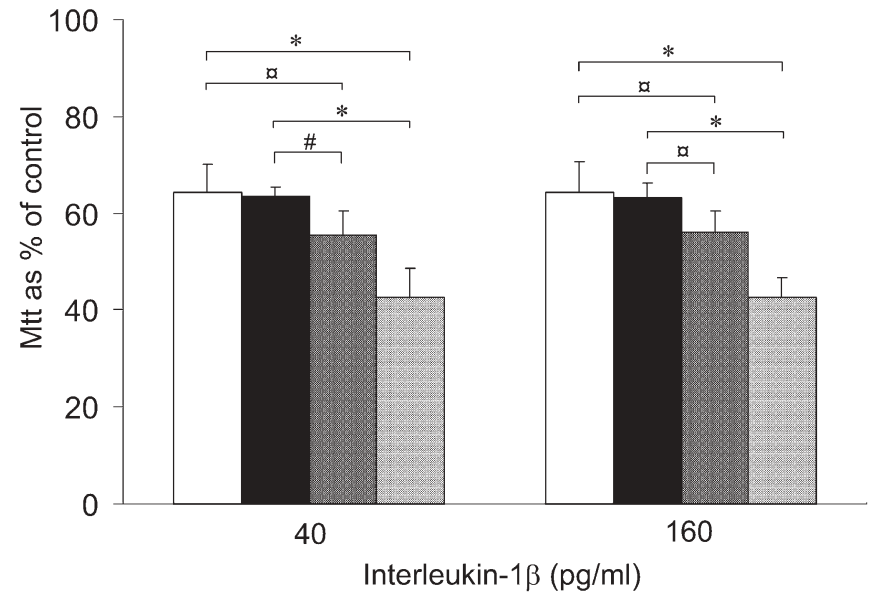

Fig. 5. Effect of Nkx6.1 on IL-1 $\beta$-induced toxicity. Viability, measured as MTT activity (percent of control) in the MSL-GAN cells (white bars), non-Nkx6.1 expressing cells (\#584, black bars) and in the Nkx6.1 positive cells (\#589, dark grey bars and \#624, light grey bars). The cells were exposed to IL$1 \beta(40 \mathrm{pg} / \mathrm{ml}$ or $160 \mathrm{pg} / \mathrm{ml})$ for 3 days. Data are means \pm SD of triplicate determinations from six independent experiments. Significant differences between the clones are indicated $(*$, $p<0.001$; \#, $p<0.01 ; \& \# 164 ;, p<0.05$ )

or in the clone \#584). Using clone \#624 with the highest Nkx6.1 expression for the initial titrations, an approximately $50 \%$ reduction in the viability was obtained at $40-160 \mathrm{pg} / \mathrm{ml} \mathrm{IL-1 \beta}$. Subsequent analyses using these concentrations of IL- $1 \beta$ revealed a significantly increased sensitivity to IL- $1 \beta$ at 40 and $160 \mathrm{pg} / \mathrm{ml}$ in both the Nkx6.1 expressing clones (\#589 and \#624) as compared to the non-Nkx6.1 expressing clone (\#584) and the parent cell line (MSL-G-AN) (Fig. 5). Clone \#624 was more sensitive to IL-1 $\beta$ compared to clone \#589, which correlates with the higher expression level of Nkx6.1 in clone \#624 compared to clone \#589 (Fig. 4).

\section{Discussion}

The criterion for a significant change in the expression level varies between studies. In previous proteome analyses $[19,21,22]$ the level of significance was chosen at $p<0.01$, whereas in previously published array analyses $[23,24,25]$ the level of significance has been based on fold changes $(\geq 2.5$ or $\geq 3)$, probably due to the very low number of independent experiments reported, not allowing statistical interpretation. The present array analyses are based on four independent experiments and classical statistical analysis. The large inter-assay differences in standard deviations (2.3 to 415; Table 1) observed emphasise the importance of using several independent experiments in GeneChip array analysis of gene expression changes. Similar large variations were observed in the experiments with IL-1 $\beta$ exposure (data not shown). We 
therefore decided to evaluate the data based on a statistically defined level of significance for expression changes, here chosen as $p<0.01$. Using this criterion we found that the expression levels of 98 fully annotated mRNAs were changed during beta cell maturation, of which IL-1 $\beta$ influenced 50. In addition, the expression of 197 mRNAs had changed in the prebeta-cell phenotype and $522 \mathrm{mRNAs}$ in the beta cell phenotype, respectively, following IL- $1 \beta$ exposure. If we looked in these groups only at mRNAs that had changed more than 2.5 fold in expression, the number of mRNAs that had changed during beta cell maturation was reduced to $83 ; 30$ mRNAs reflected both maturation and IL-1 $\beta$ exposure, and 33 and 132 exclusively reflected IL-1 $\beta$ exposure of the pre-beta-cell phenotype or the beta cell phenotype, respectively.

Our semi-quantitative RT-PCR analysis showed a good correlation with the data obtained in the GeneChip array analysis in line with a previous publication [24] suggesting that the GeneChip array technology is indeed a powerful tool to obtain a global picture of the transcript expression pattern.

The present study represents, to our knowledge, the first comparison of the effect of IL- $1 \beta$ on the gene expression profile between a pre-beta-cell phenotype, not sensitive to the toxic effect of IL-1 $\beta$, and the matured beta cell phenotype, which is highly sensitive to the deleterious properties of IL-1 $\beta$. Previous array analyses have focused on cytokine sensitivity exclusively in isolated beta cells or beta cell lines (RIN or INS-1E) [23, 24, 25]. All changes reflecting beta cell maturation and the influence of IL-1 $\beta$ on these transcripts are presented in Table 1. Since space does not allow a full list of all IL-1 $\beta$-induced changes in the two phenotypes, mRNAs presented and discussed in the manuscript reflect our hypothesis that changes in the mRNA expression profile that lead to susceptibility to IL-1 $\beta$ damage are consequences of beta cell maturation. These transcripts are presented in group A (changes during beta cell maturation) and group $\mathrm{X}, \mathrm{Y}$ and $\mathrm{Z}$ (expressions influenced by both beta cell maturation and IL-1 $\beta$ exposure). Transcripts independent of beta cell maturation (group B, C and Q) are presented and discussed in the web section. They may, in part, reflect the increased sensitivity to IL-1 $\beta$ of the beta cell phenotype (group C), or protective effects induced in the pre-beta-cell phenotype in response to IL-1 $\beta$ (group B), effects that may be lost during beta cell maturation.

Whereas the change in the mRNA expression profile defining beta cell maturation is expected to be rather stable, it should be kept in mind that changes in the mRNA expression profile following IL-1 $\beta$ exposure may vary with IL-1 $\beta$ concentration and exposure time. Hence, a different IL-1 $\beta$ concentration and/or a shorter or longer exposure time might influence the overall mRNA expression profile [25]. Here we look at late responses ( $24 \mathrm{~h} \mathrm{IL}-1 \beta$ exposure) i.e. a condition that does not allow discrimination between 'primary' and 'secondary' effects of IL- $1 \beta$. Nevertheless, our results provide a detailed picture of IL- $1 \beta$ affected pathways and mechanisms involved in the complex process of beta cell maturation and destruction by IL-1 $\beta$.

Comparison of the present array data with our recent proteome analyses of beta cell maturation using the same cellular cell system surprisingly revealed only two mRNA and proteins expression changes in common (creatine kinase and argininosuccinate synthetase) [19]. Several explanations may account for this, including the different methods of assay/sample preparation, different detection sensitivity, translational regulation, alternative splicing of certain mRNAs, selective degradation or excretion of proteins, time discrepancy between gene and protein expression, expression level and post-translational modification. Furthermore in the proteome analysis, at least $37 \%$ of the protein-changes during beta cell maturation represented post-translationally modified forms not reflected at the transcript level [19]. In addition, some transcript proteins may not be present on the GeneChip and therefore not detected as significantly changed transcripts. Finally, very low molecular weight and membrane proteins were not detectable in the proteome analysis. A recent proteome and transcriptome analysis of IL-1 $\beta$-treated ( 6 and $24 \mathrm{~h}$ ) lung carcinoma cell line found no similarities between data from the two types of analyses [33]. Nevertheless, both in the study of beta cell maturation and lung carcinoma cells the same pathways were affected in the proteome and transcriptome analyses. When comparing our array analysis with previous proteome analyses of IL- $1 \beta$ exposed WF rat islet (\&\#164; in the tables) [21] and BB rat islets (\# in the tables) [22] only 3.8\% and 3.7\%, respectively, were in common. In contrast, comparison with previous array analyses of IL- $1 \beta$ exposed RIN cells showed $36 \%$ (* in the tables) [23], cytokine exposed purified beta cells $40 \%$ ( $\S$ in the tables) [24] and cytokine exposed INS-1E cells $21 \%$ ( $\&$ in the tables) [25] identity, despite differences in the experimental conditions.

Transcript profile reflecting beta cell maturation and associated IL-1 $\beta$ response (Section I, Table 1): Beta cell specificity. Maturation from the pre-beta-cell to the beta cell phenotype was associated with up-regulation of insulin I (FC 7.0), insulin II (FC 64.5) and glucose transporter type 2 (GLUT-2) (FC 19.4) and induced expression of the homeodomain protein Nkx6.1 (FC 10.0) (Panel A, group 1 and 2), all transcripts known to be expressed in mature beta cells. We previously demonstrated an increased expression of GLUT2 in the beta cell phenotype by semi-quantitative RTPCR [18]. Nkx6.1 is important for the development of mature beta cells in the islets and disruption of the Nkx6.1 gene leads to loss of beta cell precursors [34]. Exposure to IL-1 $\beta$ resulted in down-regulation of 
Nkx6.1 (FC -3.1) and insulin II (FC -1.4) (Panel B, group 1) expression exclusively in the beta cell phenotype; both were also down-regulated after cytokine exposure of INS-1E cells [25]. GLUT-2 is involved in glucose signalling in mature beta cells and high levels of glucose have been shown to activate the expression of GLUT-2 [35]. We previously speculated that upregulated GLUT-2 expression might be responsible for the acquired sensitivity to streptozotocin accompanying the maturation of the beta cell phenotype [18]. In contrast, exposure to IL- $1 \beta$ resulted in a similar downregulation of GLUT-2 (FC -2.6 , beta cell and FC -2.8 , pre-beta cell; Panel B, group 2) expression in both phenotypes, which may result in decreased beta cell function, since decreased glucose-metabolism and insulin secretion has been associated with decreased expression of GLUT-2 [36]. GLUT-2 was also downregulated after cytokine exposure of purified beta cells [24]. Nevertheless, second-phase glucose-stimulated insulin secretion has been detected in GLUT-2 knockout mice [37]. Furthermore inositol-1,4,5-triphosphate receptor (FC 2.6) and inositol-1,4,5-triphosphate binding protein (FC 4.0) (Panel A, group 7) involved in insulin-release in mature beta cells (reviewed in [38]) were both up-regulated during maturation into the beta cell phenotype. Interestingly, inositol 1,4,5triphosphate binding protein (FC 2.3, beta cell and FC 5.0, pre-beta cell; Panel B) was up-regulated in both phenotypes following IL-1 $\beta$ exposure.

The proto-oncogene transcription factor c-myc ( $F C$ 19.5; Panel A, group 1) was induced after beta cell maturation. Increased expression of c-myc has also been found in islets of partially pancreatectomised rats with severe hyperglycaemia resulting in reduced beta cell mass and loss of insulin secretory functions [39]. Furthermore over-expression of c-myc in beta cells of transgenic mice resulted in increased apoptosis and decreased insulin gene expression [40]. The ability of c-myc to mediate cytokine-induced apoptosis appears to be dependent on phosphorylation of this proto-oncogene by mitogen activated protein kinase (MAPK) or c-Jun NH2-terminal kinase (JNK) [41, 42]. Interestingly, JNK is activated by IL- $1 \beta$ in beta cells and JNK inhibition has been shown to prevent IL-1 $\beta$-mediated beta cell apoptosis [43]. Despite down-regulation of c-myc (FC -2.0, Panel B) mRNA after IL-1 $\beta$ exposure of the beta cell phenotype, the beta cell phenotype still contains higher levels of the c-myc transcripts compared with the pre-beta cell which only shows expression at the detection limit. Our semiquantitative RT-PCR data confirmed higher levels of c-myc (NHI-glu $0.1 \pm 0.02$ vs NHI-ins $0.5 \pm 0.1$ ) in the beta-cell phenotype, however the RT-PCR data did not confirm the effect of IL- $1 \beta$ detected in the GeneChip array analysis. Decreased c-myc expression has previously been described in IL-1 $\beta$ exposed RIN cells [23], whereas increased expression of c-myc has been found in cytokine-exposed purified beta cells [24] and INS-
$1 \mathrm{E}$ cells [25]. These differences might reflect differences in experimental setup.

Glycolysis and energy generation. Four mRNAs involved in energy generation changed expression levels during beta cell maturation. Down-regulation of hexokinase (FC -11; Panel A, group 3), one of three enzymes that controls glycolysis and up-regulation of fructose-1,6-bisphosphase (FC 14.9), which stimulates gluconeogenesis, suggests a reduced level of pyruvate in the beta cells, which may lead to decreased energy generation. Decreased energy generation was also evident from our previous proteome analysis using this cell system of beta cell maturation [19]. In contrast, pyruvate kinase (FC 2.8) and aldolase B (FC 9.7) involved in glycolysis were both up-regulated during beta cell maturation. A reduced level of pyruvate in the beta cell phenotype may result from IL-1 $\beta$ exposure, since the expression levels of pyruvate $\mathrm{ki}$ nase $(\mathrm{FC}-1.5)$ and pyruvate dehydrogenase phosphatase isoenzyme 1 (FC -1.4) were decreased and fructose-1,6-bisphosphate (FC 3.1, Panel B) was increased. Fructose-1,6-bisphosphate (FC 1.7) was also up-regulated in the pre-beta-cell phenotype and decreased expression levels of aldolase $B$ ( $\mathrm{FC}-1.3$ beta cell and FC -1.3 pre-beta cell) were detected in both phenotypes.

Immune-mediated processes. Interleukin-18 (IL-18; FC 8.0, Panel A, group 4) was up-regulated during beta cell maturation. IL-18 mRNA expression has been associated with insulitis in pancreatic islets of non-obese diabetic (NOD) mice [44]. Furthermore, decreased insulin-release and induced NO production have been demonstrated in rat islets after exposure to IL-18 in combination with IL-1 $\beta$ [45]. Thus, it is conceivable that an elevated level of IL-18 in the beta-cell phenotype might potentiate increased IL- $1 \beta$ sensitivity acquired during beta-cell maturation. In contrast, IL-18 (FC -1.3; Panel B) was down-regulated following IL-1 $\beta$ exposure of the beta cell phenotype, possibly as a feedback regulation to compensate for the toxic effect of IL-1 $\beta$ and IL-18 together.

Also mechanisms affecting the beta cell interaction with the immune system were influenced during beta cell maturation. As an example a membrane glycoprotein CD200 (FC -28.3; Panel A, group 6) expressed on a broad rage of cell types was down-regulated during beta cell maturation. CD200 is known to have an inhibiting effect on activation of macrophages and myeloid cells through interaction with the CD200 receptor on these cells (reviewed in [46, 47]). Indeed using CD200 knock-out mice, an accelerated induction of the autoimmune diseases experimental allergic encephalomyelitis and collagen-induced arthritis has been demonstrated. Thus, it has been suggested that a loss of this inhibitory pathway may increase the susceptibility to tissue-specific autoimmunity and enable 
an accelerated reactivity of resident tissue macrophages [46]. It could be speculated that a reduced expression of CD200 in beta cells may have implication on the pathogenesis of T1D.

Signal transduction. MAP kinase phosphatase (cpg21) (FC -3.0; Panel A, group 7) is involved in the cytokine-signalling cascade where it de-phosphorylates MAP kinases leading to their inactivation [48]. Downregulation of cpg21 during beta cell maturation might result in an increased MAPK activity and resulting apoptosis and NO production in the beta cell phenotype following IL-1 $\beta$ exposure. Cpg21 was also down-regulated in cytokine-exposed purified beta cells [24]. Furthermore the suppressor of cytokine signalling-2 (SOCS-2; Panel A, FC 3.2) was up-regulated during beta cell maturation. Over-expression of SOCS-1 and SOCS-3 (not present on the GeneChip) has been shown to protect against cytokine-induced beta cell destruction [49, 50], whereas the involvement of SOCS-2 in cytokine-induced beta cell destruction still needs to be elucidated.

Arginine metabolism and NO formation. Argininosuccinate synthetase (AS; Panel A, group 8) is involved in the conversion of citrulline to arginine in the ureacycle and down-regulation of AS results in citrullinaemia [51]. Production of urea in rat islets has been shown after addition of arginine, due to expression of several of the urea-cycle enzymes [52]. Therefore the substantial down-regulation of AS (FC -16.6) during beta cell maturation might result in increased levels of citrulline. Down-regulation of AS (ratio $0.2 \sim$ FC -5 ) was also found in proteome analysis of these cells [19]. Deficiency of AS may also lead to increased amounts of ammonia and decreased amounts of arginine [53]. An increased expression of glutamine synthetase (FC 2.4, group 13) in the beta cell phenotype was detected, possibly as a compensation for the increased levels of ammonia, since glutamine synthetase is involved in the detoxification of ammonia [54]. Furthermore, it could be speculated that the beta cell phenotype compensates for the low arginine levels by activating several pathways to increase the levels of arginine. Arginine may be provided from the extracellular pool by protein degradation [55] or by feedback repression of arginine-glycine amidinotransferase (FC 4.5, group 13), which converts arginine to ornithine and guanidinoacetate [56]. Creatine feedback suppresses this reaction [56] and increased levels of creatine in the beta cell phenotype could result from the observed down-regulation of creatine kinase (FC -10.3, Panel A, group 3). In contrast, $A S$ was up-regulated in both phenotypes after IL- $1 \beta$ exposure although highest in the beta-cell phenotype (pre-beta cell, FC 24.9 and beta cell, FC 74.0; Panel B). An upregulated expression of AS was also detected in cytokine-exposed purified beta cells [24] and INS-1E cells
[25] and creatine kinase was also up-regulated in purified beta cells [24]. IL-1 $\beta$ has been demonstrated to induce iNOS expression, which converts arginine and oxygen to citrulline and NO (reviewed in [57]). Recycling of citrulline into arginine and co-induction of iNOS and AS [58] has been demonstrated in macrophages, suggested as a mechanism to regulate NO production [59]. Furthermore, in IL-1 $\beta$ exposed beta cells increased arginine levels and activation of the citrulline-NO cycle with expression of AS have been demonstrated [60]. This is in line with our finding of induced AS expression in both phenotypes and with our previous analyses demonstrating the same level of IL-1 $\beta$-induced NO production in both phenotypes [18]. Exposure of IL-1 $\beta$ in both phenotypes resulted in increased expression of creatine kinase (FC 3.9, beta cell and FC 4.7, pre-beta cell; Panel B), which may be a result of the increased expression of AS in both phenotypes. Several other transcripts involved in this pathway were also changed after IL- $1 \beta$ exposure of the beta cell phenotype, but not influenced by the maturation process (presented and discussed in Table C, see Electronic Supplementary Material). The importance of enzymes involved in the regulation of the urea cycle for the acquired IL- $1 \beta$-mediated beta cell destruction needs to be further analysed.

Defence/repair mechanism. A possible increase in defence/repair mechanisms during beta cell maturation was detected as highly up-regulated expression of $g l u$ tathione-S-transferase (GST) (FC 52.6) and two subclasses of GST (FC 2.2, FC 8.6) as well as of glutathione peroxidase (GP) (FC 34.6) and Gas5 growth arrest (FC 2.8; Panel A, group 10). Increased expression of GP during beta cell maturation was confirmed by semi-quantitative RT-PCR (NHI-glu $n d$ vs NHI-ins $1102 \pm 147$, Table 2), which also explains the high FC value in Table 1, since GP is up-regulated from an expression level around the detection limit of the GeneChip array assay (indicated by an ' $\wedge$ ' behind the FC value in Table 1). This was confirmed by our semi-quantitative RT-PCR analysis (Fig. 2). GST works together with glutathione in the decomposition of hydrogen peroxide $\left(\mathrm{H}_{2} \mathrm{O}_{2}\right)$ or other organic hydroperoxides (reviewed in [61]). Glutathione has been demonstrated to protect human insulinoma cells against the toxic effects of tumor necrosis factor $\alpha$ (TNF- $\alpha$ ) [13], and together with catalase, GP protects RIN cells against $\mathrm{H}_{2} \mathrm{O}_{2}$, reactive oxygen species and cytokines [14]. Despite this up-regulation of defence mechanisms in the beta cell phenotype the levels of antioxidant capacity may still be low, since previous studies revealed that pancreatic islets contain low levels of antioxidant enzymes compared with other tissues $[62,63]$ and the absolute levels of antioxidants in the pre-beta-cell and the beta cell phenotype are not determined. Nevertheless, this increase in defence is not sufficient to prevent IL-1 $\beta$-induced destruction of 
the beta cell phenotype [18]. Exposure to IL-1 $\beta$ resulted in a small further up-regulation of two subclasses of GST in both phenotypes, whereas GP (FC -1.3) was exclusively down-regulated in the beta cell phenotype following IL-1 $\beta$ exposure (Panel B). Downregulation of metallothionein-1 and 2 (FC -2.2, Panel A) may also render the beta cells susceptible to the toxic effects of IL-1 $\beta$, since it has been shown that over-expression of metallothionein in beta cells reduces streptozotocin-induced DNA damage and diabetes [15]. Exposure to IL- $1 \beta$ resulted in further downregulation of metallothionein- 1 and 2 in both phenotypes although significantly $(p<0.001)$ lowest in the beta-cell phenotype (FC -4.7 vs FC -2.2 ; Panel B).

In summary, the changed mRNAs expression profiles during beta cell maturation reflected increased expression of several mRNAs known to be present in mature native beta cells. In addition, several pathways that could explain increased sensitivity to the toxic effects of IL-1 $\beta$ were modulated. The changes in the transcript profiles following IL- $1 \beta$ exposure of the two phenotypes discussed here and at the web site (web address) reflect an increased sensitivity of the beta cell phenotype to IL-1 $\beta$, e.g. shown by decreased expression of transcripts encoding proteins involved in energy generation, glucose transport and insulin release. IL-1 $\beta$ effects on the beta cell phenotype were also associated with NO production, apoptosis and changes related to activation and interaction with cells of the immune system, which may further amplify beta cell destruction.

Functional analyses of $P d x-1$ and Nkx6.1 (Part III). Transcription factors like Pdx-1 and Nkx6.1 are required for maturation and function of the insulin-producing beta cells $[4,7]$. Pdx-1 is expressed both in the pre-beta-cell and in the beta cell phenotype, whereas activation of Nkx6.1 expression occurs during maturation into the IL-1 $\beta$-sensitive beta cell phenotype [26]. Our previous analyses demonstrated this maturation to be associated with IL-1 $\beta$ sensitivity [18]. This suggests that Pdx-1 may be necessary, but not sufficient, to induce IL-1 $\beta$ sensitivity and that the activation of Nkx6.1 plays an important role in this process. In our array analyses, we confirmed up-regulation of Nkx6.1 (FC 10.0) (Table 1, group 1) during beta-cell maturation. Decreased expression levels of both Pdx-1 (FC 1.4) (Table $\mathrm{C}$, web address) and Nkx6.1 (FC -3.1) (Table 1, group 1) were found after IL-1 $\beta$ exposure. To further address the role of Pdx-1 and Nkx6.1 two other cellular systems of beta cell maturation based on inducible or stable over-expression of the two transcription factors were used. In previous studies of the INS- $1 \alpha \beta$ cells with inducible Pdx-1 expression, a concomitant induction of Nkx6.1 was demonstrated together with a decrease in the glucagon expression levels and an increase in Glut-2 expression and insulin content [27]. Here we demonstrated that induction of
Pdx-1 expression by addition of doxycycline also rendered the cells sensitive to IL-1 $\beta$ (Fig. 3). In contrast, doxycycline induction of a DN-Pdx-1 construct did not induce IL-1 $\beta$ sensitivity. To focus our analysis on the role of Nkx6.1, a Pdx-1 negative cell system with over-expression of Nkx6.1 was used [28]. Transfection with Nkx6.1 induced a beta cell phenotype, associated with a small increase in insulin content (mRNA level and immunostaining) [28]. We demonstrated that induced Nkx6.1 expression alone in the Pdx-1 negative cells was able to further increase IL- $1 \beta$ sensitivity (Fig. 5). Thus, our data suggest that sequential activation of transcription factors involved in beta-cell maturation makes the beta cells increasingly more sensitive to IL-1 $\beta$. We hypothesise that Pdx-1 expression induces IL-1 $\beta$ sensitivity in part by induced Nkx6.1 transcription and subsequent induction of Nkx6.1 dependent genes. Future analyses are required to demonstrate to what extent Pdx.1 and in particular Nkx6.1 regulated genes are important for the acquired IL-1 $\beta$ sensitivity of mature beta cells. Combining the data presented here with future classification of the genes regulated by these transcription factors might finally reveal which of the many IL- $1 \beta$-induced transcripts that are primarily responsible for the IL- $1 \beta$-mediated toxicity characteristic of beta cells.

In summary, the changes in the mRNA expression profiles during beta cell maturation and IL- $1 \beta$ exposure revealed that several pathways affected as a result of beta cell maturation were further influenced after IL- $1 \beta$ exposure. In addition, IL- $1 \beta$ had effects on several other pathways in the beta cell phenotype not directly related to the maturation process. This is in line with our hypothesis that the increased sensitivity to IL$1 \beta$ is a trait acquired during beta cell maturation and that cytokines induce a race between protective and deleterious mechanisms in beta cells, and when the deleterious ones prevail, beta cell destruction in vitro and perhaps T1D in vivo develops [8]. This view also finds support in our previous proteome studies of beta cell maturation, where similar pathways were affected [19]. After IL-1 $\beta$ exposure of both the beta cell and the pre-beta-cell phenotype several mRNA expressions were similarly changed, showing that deleterious and protective mechanisms were activated in both phenotypes. Thus, it seems to be the overall balance that determines the fate of the individual phenotype. Furthermore, many of the changes are not quantitatively large changes, suggesting that the fate of the beta cells is not determined by expression changes of one or very few specific mRNAs, but rather is dependent upon the combined effects of several changes. Activation of Pdx-1 and particular Nkx6.1 dependent genes during beta cell maturation may represent regulatory transcriptional networks necessary for IL- $1 \beta$-induced beta cell destruction and should be studied further.

Clearly, additional analyses are needed to elucidate the functional importance of the different transcripts 
and encoded proteins in cytokine-mediated beta cell destruction or spontaneous T1D. Such knowledge may provide useful information for the design of preventive and/or curative strategies in T1D.

Acknowledgements. The technical skills and expertise of Susanne Munch and Ellis Schjerning are greatly appreciated. We are very grateful to Helle V. Petersen for the immunocytochemistry staining of the cells. This study was in part supported by grants from the Danish Diabetes Association, Danish Medical Research council (grant no. 9902341), the Sehested Hansen Foundation, Danish National Biotechnological Instrument Centre (DABIC), a Focused Type 1 Research Grant from European Foundation for the Study of Diabetes, the Juvenile Diabetes Research Foundation (RFA DK-99-002) and a Biotech grant from the Danish Medical Research council (grant no. 9502027).

\section{References}

1. Pictet RL, Rutter WJ (1972) Development of the embryonic endocrine pancreas. Handb Physiol 1:25-66

2. Servitja JM, Ferrer J (2004) Transcriptional networks controlling pancreatic development and beta cell function. Diabetologia 47:597-613

3. Herrera PL (2000) Adult insulin- and glucagon-producing cells differentiate from two independent cell lineages. Development 127:2317-2322

4. Jensen J, Heller RS, Funder-Nielsen T et al. (2000) Independent development of pancreatic alpha- and beta-cells from neurogenin 3-expressing precursors: a role for the Notch pathway in repression of premature differentiation. Diabetes 49:163-176

5. Offield MF, Jetton TL, Labosky PA et al. (1996) PDX-1 is required for pancreatic outgrowth and differentiation of the rostral duodenum. Development 122:983-995

6. Guz Y, Montminy MR, Stein R et al. (1995) Expression of murine STF-1, a putative insulin gene transcription factor, in beta cells of pancreas, duodenal epithelium and pancreatic exocrine and endocrine progenitors during ontogeny. Development 121:11-18

7. Oster A, Jensen J, Serup P et al. (1998) Rat endocrine pancreatic development in relation to two homeobox gene products (Pdx-1 and Nkx 6.1). J Histochem Cytochem 46:707-715

8. Nerup J, Mandrup-Poulsen T, Helqvist S et al. (1994) On the pathogenesis of IDDM. Diabetologia 37 Suppl 2:S82S89

9. Mandrup-Poulsen T (1996) The role of interleukin-1 in the pathogenesis of IDDM. Diabetologia 39:1005-1029

10. Rabinovitch A, Suarez-Pinzon WL, Strynadka K, Lakey JR, Rajotte RV (1996) Human pancreatic islet beta-cell destruction by cytokines involves oxygen free radicals and aldehyde production. J Clin Endo Met 81:3197-3202

11. Delaney CA, Pavlovic D, Hoorens A, Pipeleers DG, Eizirik DL (1997) Cytokines induce deoxyribonucleic acid strand breaks and apoptosis in human pancreatic islet cells. Endocrinology 138:2610-2614

12. Sandler S, Bendtzen K, Borg L et al. (1989) Studies on the mechanism causing inhibition of insulin secretion in rat pancreatic islets exposed to interleukin-1 $\beta$ indicate a perturbation in the mitochondrial function. Endocrinology 124:1492-1501

13. Cavallo MG, Monetini L, Valente L et al. (1997) Glutathione protects a human insulinoma cell line from tumor ne- crosis factor-alpha-mediated cytotoxicity. J Clin Lab Res 27:44-47

14. Lortz S, Tiedge M, Nachtwey T et al. (2000) Protection of insulin-producing RINm5F cells against cytokine-mediated toxicity through overexpression of antioxidant enzymes. Diabetes 49:1123-1130

15. Chen HN, Carlson EC, Pellet L, Moritz JT, Epstein PN (2001) Overexpression of metallothionein in pancreatic beta-cells reduces streptozotocin-induced DNA damage and diabetes. Diabetes 50:2040-2046

16. Madsen OD, Andersen LC, Michelsen B et al. (1988) Tissue-specific expression of transfected human insulin genes in pluripotent clonal rat lines induced during passage in vivo. Proc Natl Acad Sci USA 85:6652-6656

17. Madsen OD, Andersen LC, Serup P, Michelsen B (1989) Control of insulin gene expression in pluripotent rat islet tumor cells. Elsevier, Biomedical Division, pp 141-153

18. Nielsen K, Karlsen AE, Deckert M et al. (1999) Beta-cell maturation leads to in vitro sensitivity to cytotoxins. Diabetes 48:2324-2332

19. Nielsen K, Sparre T, Larsen MR et al. (2004) Protein expression changes in a cell system of beta-cell maturation reflect an acquired sensitivity to IL-1 $\beta$. Diabetologia $47 \mathrm{t}: 62-74$

20. Lockhart DJ, Dong H, Byrne MC et al. (1996) Expression monitoring by hybridization to high-density oligonucleotide arrays. Nat Biotechnol 14:1675-1680

21. Mose Larsen P, Fey SJ, Larsen MR et al. (2001) Proteome analysis of interleukin-1 $\beta$-induced changes in protein expression in rat islets of Langerhans. Diabetes 50:10561063

22. Sparre T, Christensen UB, Larsen PM et al. (2002) IL-1 $\beta$ induced protein changes in diabetes prone $\mathrm{BB}$ rat islets of Langerhans identified by proteome analysis. Diabetologia 45:1550-1561

23. Rieneck K, Bovin LF, Josefsen K et al. (2000) Massive parallel gene expression profiling of RINm5F pancreatic islet $\beta$-cells stimulated with interleukin-1 $\beta$. APMIS 108:855-872

24. Cardozo AK, Kruhoffer M, Leeman R, Orntoft T, Eizirik DL (2001) Identification of novel cytokine-induced genes in pancreatic $\beta$-cells by high-density oligonucleotide arrays. Diabetes 50:909-920

25. Kutlu B, Cardozo AK, Darville MI et al. (2003) Discovery of gene networks regulating cytokine-induced dysfunction and apoptosis in insulin-producing INS-1 cells. Diabetes 52:2701-2719

26. Jensen J, Serup P, Karlsen C, Nielsen TF, Madsen OD (1996) mRNA profiling of rat islet tumors reveals Nkx6.1 as a $\beta$-cell-specific homeodomain transcription factor. $\mathbf{J}$ Biol Chem 271:18749-18758

27. Wang HY, Maechler P, Ritz-Laser B et al. (2001) Pdx1 level defines pancreatic gene expression pattern and cell lineage differentiation. J Biol Chem 276:25279-25286

28. Jørgensen MC, Vestergard-Petersen H, Ericson J, Madsen OD, Serup P (1999) Cloning and DNA-binding properties of the rat pancreatic beta-cell-specific factor Nkx6.1. FEBS Lett 461:287-294

29. Madsen OD, Larsson L-I, Rehfeld JF et al. (1986) Cloned cell lines from a transplantable islet cell tumor are heterogeneous and express cholecystokinin in addition to islet hormones. J Cell Biol 103:2025-2034

30. Blume N, Skouv J, Larsson L-I, Holst JJ, Madsen OD (1995) Potent inhibitory effects of transplantable rat glucagonamas and insulinomas on the respective endogenous islet cells are associated with pancreatic apoptosis. J Clin Invest 96:2227-2235 
31. Serup P, Petersen HV, Pedersen EE et al. (1995) The homeodomain protein IPF-1/STF-1 is expressed in a subset of islet cells and promotes rat insulin 1 gene expression dependent on an intact E1 helix-loop-helix factor binding site. Biochem J 310:997-1003

32. Mosmann T (1983) Rapid colorimetric assay for cellular growth and survival: application to proliferation and cytotoxicity assay. J Immunol Methods 65:55-63

33. Kim CH, Kim DK, Choi SJ et al. (2003) Proteomic and transcriptomic analysis of interleukin-1 beta treated lung carcinoma cell line. Proteomics 3:2454-2471

34. Sander N, Sussel L, Conners J et al. (2000) Homeobox gene Nkx6.1 lies downstream of Nkx2.2 in the major pathway of $\beta$-cell formation in the pancreas. Development 127:5533-5540

35. Ferrer J, Gomis R, Fernandez Alvarez J, Casamitjana R, Vilardell E (1993) Signals derived from glucose metabolism are required for glucose regulation of pancreatic islet GLUT2 mRNA and protein. Diabetes 42:1273-1280

36. Yoshikawa H, Tajiri Y, Sako Y et al. (2001) Effects of free fatty acids on beta-cell functions: a possible involvement of peroxisome proliferator-activated receptors alpha or pancreatic/duodenal homeobox. Metab Clin Exp 50:613618

37. Guillam MT, Hümmler E, Schaerer E et al. (1997) Early diabetes and abnormal postnatal pancreatic islet development in mice lacking Glut-2. Nat Genet 17:327-330

38. Hagar RE, Ehrlich BE (2000) Regulation of the type III Ins $\mathrm{P}_{3}$ receptor and its role in $\beta$-cell function. Cell Mol Life Sci 57:1938-1949

39. Laybutt DR, Glandt M, Xu G et al. (2003) Critical reduction in beta-cell mass results in two distinct outcomes over time. Adaptation with impaired glucose tolerance or decompensated diabetes. J Biol Chem 278:2997-3005

40. Laybutt DR, Weir GC, Kaneto H et al. (2002) Overexpression of c-Myc in beta-cells of transgenic mice causes proliferation and apoptosis, downregulation of insulin gene expression, and diabetes. Diabetes 51:1793-1804

41. Noguchi K, Kitanaka C, Yamana H et al. (1999) Regulation of c-Myc through phosphorylation at Ser-62 and Ser71 by c-Jun N-terminal kinase. J Biol Chem 274:32580-32587

42. Noguchi K, Yamana H, Kitanaka C et al. (2000) Differential role of the JNK and p38 MAPK pathway in c-Myc- and s-Myc-mediated apoptosis. Biochem Biophys Res Commun 267:221-227

43. Ammendrup A, Maillard A, Nielsen K et al. (2000) The cJun amino-terminal kinase pathway is preferentially activated by interleukin-1 and controls apoptosis in differentiating pancreatic beta-cells. Diabetes 49:1468-1476

44. Rothe H, Hibino T, Itoh Y, Kolb H, Martin S (1997) Systemic production of interferon-gamma inducing factor (IGIF) versus local IFN-gamma expression involved in the development of Th1 insulitis in NOD mice. J Autoimmun 10:251-256

45. Hong TP, Andersen NA, Nielsen K et al. (2000) Interleukin-18 mRNA, but not interleukin-18 receptor mRNA, is constitutively expressed in islet beta-cells and upregulated by interferon-gamma. Eur Cytokine Netw 11:193-205
46. Hoek RH, Ruuls SR, Murphy CA et al. (2000) Down-regulation of the macrophage lineage through interaction with OX2 (CD200). Science 290:1768-1771

47. Barclay AN, Wright GJ, Brooke G, Brown MH (2002) $\mathrm{CD} 200$ and membrane protein $\mathrm{E}$ interactions in the control of myeloid cells. Trends Immunol 23:285-290

48. Hevroni D, Rattner A, Bundman M et al. (1998) Hippocampal plasticity involves extensive gene induction and multiple cellular mechanisms. J Mol Neurosci 10:75-98

49. Flodström-Tullberg M, Yadav D, Hagerkvist R et al. (2003) Target cell expression of suppressor of cytokine signaling-1 prevents diabetes in the NOD mouse. Diabetes 52:2696-2700

50. Karlsen AE, Ronn SG, Lindberg K et al. (2001) Suppressor of cytokine signaling 3 (SOCS-3) protects beta cells against interleukin-1 $\beta$ - and interferon- $\gamma$-mediated toxicity. Proc Natl Acad Sci USA 98:12191-12196

51. Kobayashi K, Rosenbloom C, Beaudet AL, O'Brien WE (1991) Additional mutations in argininosuccinate synthetase causing citrullinemia. Mol Biol Med 8:95-100

52. Sener A, Blachier F, Malaisse WJ (1988) Production of urea but absence of urea cycle in pancreatic islet cells. Med Sci Res 16:483-484

53. Powers-Lee SG, Meister A (1988) Urea synthesis and ammonia metabolism. In: Jakoby WB, Popper H, Schachter D, Shafritz DA (eds) The liver and pathobiology (2nd edition). Raven Press, New York pp 317-330

54. Mill JF, Mearow KM, Purohit HJ et al. (1991) Cloning and functional characterization of the rat glutamine synthetase gene. Brain Res Mol Brain Res 9:197-207

55. Wu G, Morris SM (1998) Arginine metabolism: nitric oxide and beyond. Biochem J 336:1-17

56. Guthmiller P, Van-Pilsum JF, Boen JR, McGuire DM (1994) Cloning and sequencing of rat kidney L-arginine:glycine amidinotransferase. Studies on the mechanism of regulation by growth hormone and creatine. J Biol Chem 269:17556-17560

57. Eizirik DL, Pavlovic D (1997) Is there a role for nitric-oxide in beta-cell dysfunction and damage in IDDM. Diabetes Metab Res Rev 13:293-307

58. Nussler AK, Billiar TR, Liu ZZ, Morris SM (1994) Coinduction of nitric oxide synthase and argininosuccinate synthetase in a murine macrophage cell line. Implications for regulation of nitric oxide production. $\mathrm{J}$ Biol Chem 269:1257-1261

59. Wu GY, Brosnan JT (1992) Macrophages can convert citrulline into arginine. Biochem J 281:45-48

60. Flodström M, Chen MC, Smismans A et al. (1999) Interleukin- $1 \beta$ increases arginine accumulation and activates the citrulline-NO cycle in rat pancreatic beta cells. Cytokine 11:400-407

61. Dickinson DA, Forman HJ (2002) Glutathione in defense and signaling: lessons from a small thiol. Ann NY Acad Sci 973:488-504

62. Malaisse WJ, Malaisse-Lagae F, Sener A, Pipeleers DG (1982) Determinants of the selective toxicity of alloxan to the pancreatic $\beta$-cell. Proc Natl Acad Sci USA 79:927-930

63. Lenzen S, Drinkgern J, Tiedge M (1996) Low antioxidant enzyme gene expression in pancreatic islets compared with various other mouse tissues. Free Radic Biol Med 20:463-466 